\title{
The Utterance Of Prohibition Form As A Harmony Existence In The Tengger Community
}

\author{
Dwi Handayani \\ \{dwihanda1967@yahoo.co.id\} \\ Faculty of Cultural Sciences, Airlangga University
}

\begin{abstract}
The utterance of prohibition form is one way to maintain harmony for a society. That various of prohibition forms is function as a maintaining harmony existence in social relations, both human relations with humans, humans with society as well as human relations with the natural surroundings. The Tengger community is known for being a very adaptive, open and harmonious society. In this case, the Tengger community easily adapts to anyone, and is always open with newcomers so that daily life is going very harmonious. The utterance of prohibitionis a way for parents to give advice to their children to control attitudes and behavior that can harm themselves and others. In this point, the Tenggercommunityvery maintain harmony in social life by preserve the utterance of prohibition which have noble values that can be passed down through generations. One example of autterance of prohibition form that is advice for the Tengger community, i.e.njupuk sakdom mbalikno sakpicuk 'taking one needle will return sakpicuk (sakpicuk means to return a larger amount)'.The utterance of prohibition form above gives an advice that the law of karma applies to life in the world and the hereafter, namely if someone steals someone else's property as small as a needle, so then that person will lose even more. In this case it can be seen that the life of the Tengger community is very harmonious, there has never been theft even though the house was left behind by the owner in an open and unlocked condition. As for the utterance of prohibition formcan be implemented for other communities so that a harmonious life can be maintained and preserve conductively.
\end{abstract}

Key words: Utterance, forms of prohibition, Tengger community

\section{Introduction}

The form of local wisdom that can be passed down from generation to generation is part of cultural heritage that contains the wisdom values of a particular region. Furthermore, a local wisdom is based on the values of goodness that are trusted, applied and always maintained in a certain period of time by a group of community. One of local wisdom form that can be give on for their next generations is through storyfrom mouth to mouth as a form of oral tradition, namely the utterance of prohibition form [1].

The utterance of prohibition formin a society is the way of parents in ancient time to give suggestion, advice, or teachings by using language tools that contain particular power as social 
interaction and the development of harmonization of life for the community [2]. As social interaction, the role of language expression is very important as a tool to work together, exchange ideas, and think critically. As a cultural development, language functions as an effort to establish the character of society. That characters formation is related to the philosophy of life and a sense of desire to group with other communities [3].

As oral language, the utterance of prohibition formare intended for someone to convey a prohibition on an act by using negative words or rejection, such as don't, may not, prohibited, etc [4]. The medium of oral language delivery can be through storytelling, speaking, telling or retelling of suggestion, advice or experience that has been there before. The way of using that the language is closely related to what is said, what is captured, what is meaning and what is interpreted in the form of a person's mind which obtained from the context that can be observed. Furthermore, Wijana states that in the context of speech it must involve several aspects, such as speakers and interlocutors, the context of speech, goals, actions or activities of a person as a verbal product [5]. Basically, oral tradition can be used as a cultural power which is refers to the formation of identity insideto build human civilization. Hereinafter, oral traditions are not merely used as narratives, but rather a concept of cultural heritage that should be able to be preserved and nurtured. In a research submitted by Dr. Pudentia that research about tradisi lisan (oral tradition) not just ordinary speech but its concept as a legacy power on cultural products with us as social beings [6]. In addition, the oral tradition includes the community and the context and can be used to resolve conflicts in the community.

Oral tradition discourse not only in the form of prohibitions, but can be through appeals or messages that contain advice or wejanganwhich is positive value [7]. This is keep in mind that the transformation of values and norms of life has been changed from era to era. Oral tradition culture as one form of tradition is usually in the form of advice sentences, prohibited sentences, proverbs, which refers to idiomatic forms by using direct or indirect markers on something that is mystical, or superstitious. However, earlier people emphasized that the form of the prohibition must indeed be avoided because it will become a reality if violated and not carried out. As a result, initially what was considered mystical turned into realistic.

As for the area which is being the location of research on the utterance of prohibition formthat are still maintained in life, namely the Tengger indigenous community. The Tengger region is an indigenous community that until now has held strong traditions of various heritage so that its local wisdom is positive, conducive and harmonious [8]. The Tengger community is an indigenous community who embrace Hinduism. Hinduism is strong enough to change the basic pattern of life and life behavior of these society. In addition, the Tenggercommunity always uphold the teachings of their ancestors and faithfully inherit customs in the era of modern culture. In this case, states that the Tenggercommunity are also open, they are not a primitive tribe, an isolated tribe, or other tribes that are different from the Javanese [9]. For the Tengger community, belief in something mystical is still believed to be something that brings blessing or vice versa [10]. Therefore, in social life people must be careful in speaking and behaving [11].

\section{Research Method}

The method is a way of thinking that works well to achieve the intention and obtain maximum results in a study. Sudaryanto said that the method as a way step of working must be described according to the tools and the nature of the tools used, namely through its 
techniques [12]. Furthermore, states that the research method is the tool, procedure and technique which ischosen in conducting research when collecting data [13].

Based on the using of the above methods, this study uses three strategic stages, namely (1) data collection methods, (2) data analysis methods, and (3) methods of data analysis results exposure. The following three strategic stages will be explained in connection with the method to be achieved in the research.

\section{Data Collection Method}

The method used in data collection is using the listening method, which is listening to verbal communication that is directly spoken by the Tengger community in daily communication. This acquisition data is obtained by listening to the data without any manipulation. Furthermore, research data which is relating to utterance of prohibition formare listened to and recorded in full on data cards in the form of orthographic writing. Besides listening method, researchers netted all data in the field by conducting observations in the research field and make in-depth interviews.

This interview was conducted by researchers in order to obtain accurate and complete data, especially on the utterance of prohibition in the Tengger community. In this interview activity, the researcher will link beliefs to utterance of prohibitionassociated with present life. To conduct the interview activity of course requires the informants, namely community leaders, traditional shaman, as well as the people chosen purposively.

2. Data Analysis Method

Data analysis method is the most important stage in a research because it tries to examine and analyze data in accordance with the problem formulation. At this stage, the researcher examines data in the form of utterance of prohibition, by dividing, checking, grouping, and classifying data.

3. Methods of Data Analysis Results Exposure

Exposure of the data analysis result can be done in two ways, namely by using formal methods and informal methods. Form of exposure with formal methods, namely writing down the results of the analysis by writing in orthographic sentences and using symbols or codes in linguistics. Form of exposure with informal methods is to write in words or orthographicsentences without any particular symbols.

\section{Results And Discussion}

The utterance of prohibition formis a way of parents in ancient times to give suggestion, advice, invitations, whether in the form of suggestions or prohibitions on family, environment or community [14]. Every parents suggestion and advice in ancient times was aimed to family kindness, especially to their children to control attitudes and behavior. As an indigenous community, the Tengger tribe is clearly become an unique and interesting phenomenon to be studied in the midst of public pessimism in preserving traditional values that have begun to fade by the times. The Tengger Indigenous community have become a phenomenon, because until now various existing cultural systemshave been able to be maintained and at once developed to be an important part of the cultural dynamics of their communities [15]. The form of prohibition conveyed by the Tengger community is found in the form of idioms.

A. The Utterance of Prohibition Form in the Tengger Community.

(1) Njupuke sakdom, mbalikno sakpicuk

'Taking one needle, return sakpicuk' 
The data above is a form of prohibition in the form of idioms, that is, utterance consisting of elements of language that have certain meanings. For the Tengger community, the use of these utterance has certain meanings that are very influential in life. Utterance njupuke sakdom, mbalikno sakpicuk contains a certain meaning that a law of karma applies in life in this world and the hereafter. The Tengger community is strongly believes that thoseutterance will have a negative effect on the perpetrators, meaning that if someone steals someone else's property even if it is only a small amount, they will be rewarded for losing a bigger asset.

For the Tengger community, the concept of utterance njupuke sakdom, mbalikno sakpicuk can give broadly. According to an informant a traditional shaman, the existence of the Tengger community is strongly believes that retribution of the law of karma is still valid in the process of life. Therefore, do not ever steal, do not ever cheat because the consequences are more than that. By this existence concept, we see the houses of citizens left openwhen they are go to work, never locked because they believe that their homes have never been stolen.

(2) Don't speak carelessly wherever you are

The utterance of prohibition formthat advised by parents when a child go away or outside his village, i.e. "Ojok ngomong sembarangan nok parang". The data above is utterance of formusing language elements that have clear meanings. For the Tengger community, keeping oral speaking is very important especially outside the village. Everyone should be able to maintain their speech because it can affect themselves. According speech of Mrs. Sriyati (65 years old), Ngadisari villagers said that there was a neighbor who was not speaking well when he was outside the village, for example the village was not clean, the place singup (haunted), the tree is dried and others, shortly after the person is seriously ill and difficult to recover. While help by a shaman, that person can only be cured by holding a salvation or certain rituals. Therefore, keeping the speech, keeping the attitude, keeping the tongue, which will be spoken to other people or making any comments, should be careful [16]. While the values contained in the utterance that everyone must maintain their verbal. For the Tengger community, keeping talking with others is very important because once a wrong speak will be fatal. Therefore, social relations in a relationship between relationships with individuals and certain groups must be maintained.

(3) Sepi ing pamrih, rame ing gawe

Concept sepi ing pamrih, rame ing gawe is prohibition form that everyone should not be arrogant moreover proud of what they have.For the Tengger community, if you want to help other people or groups done seriously without expecting anything in return. So it appears that if there are residents who have a celebration or are experiencing disasters, they work together and are willing to help without expecting anything in return (without any tendency).

(4) Prohibition from getting pregnant before marriage

One form of prohibition aimed at a girl before marriage, i.e.Ojok hamil sakdurunge kawin 'don't get pregnant before marriage'. For the Tengger community, parents give very strong advice, which is a girl not to be allowed get pregnant outside of marriage. If this happeneda marriage outside of marriage, there will be a disaster in the village so that the village clean ceremony must be performed. The village clean ceremony is carried out in a way mengarak (paraded) these women and men because they were considered defaming the name of their village. In data (4) parents advise that pregnant people are prohibited to take a bath at night. This is clearly prohibited because it will have an impact on the length of time when giving birth to a child so that it has an impact on the safety of the mother and child.

Furthermore, there is actually a prohibition also for pregnant women, which is prohibited to soaking the laundry so that the baby will not get difficulties when born. There are many more utterance of prohibition form that need to be aware, for example being prohibited from 
going out during sunset, killing animals, sitting near the door, singing in the kitchen, and so on.

(5) Don't marry someone whose house is face to face.

Actually the utterance of prohibitionabout the location of the house can be an appeal to a child who chooses his soul mate. Thatutterance is advised by parents to their children, namely to urge their children not to marry someone whose house is face to face. For the Tengger community, to choose a potential mate in fostering households also needs to be considered, because of the opinion for the Tengger community that people who are married to neighbors in front of the house can trigger a household rift. It is also seen that for a woman it is forbidden to get a mate from outside Tengger so that their mate is not taken outside the village, and is expected able to marry someone who is indeed a Tengger people.

\section{Conclusion}

In the cultural traditions of the Tengger community there is local wisdom that is indeed exemplary and learned for a more harmonious and adaptive life. To maintain a harmonious life, it is necessary need to pay attention to the advice of parents, ancestors who have given suggestion, advice, advice through oral traditions by using utterance of prohibition form. Basically, every parents utterance in the ancient time is aimed for family kindness, specifically for children to control attitudes and behavior.

\section{References}

[1] Danandjaja, James. Folklor Indonesia. Jakarta: Pustaka Utama Grafiti, 1991.

[2] Rahyono, F.X. Kearifan Budaya dalam Kata. Jakarta:Wedatama Widya Sastra, 2009.

[3] Sibarani, Robert. Kearifan Lokal :Hakikat, Peran, dan Metode Tradisi Lisan. Jakarta: Asosiasi Tradisi Lisan (ATL), 2012.

[4] Departemen Pendidikan Nasional. Kamus Baru Bahasa Indonesia. Jakarta: Balai Pustaka, 2008.

[5] Wijana, I Dewa Putu. Dasar-Dasar Pragmatik. Yogyakarta: ANDI, 1996.

[6] Pudentia. Metodologi Kajian Tradsi Lisan. Jakarta: Yayasan Pustaka Obor Indonesia, 2015.

[7] Chaer, Abdul. Semantik Bahasa Indonesia. Jakarta: Rineka Cipta, 1994.

[8] Pudentia. Metodologi Kajian Tradsi Lisan. Jakarta: Yayasan Pustaka Obor Indonesia, 2015.

[9] Sutarto, Ayu. Analisis Struktural Legenda Masyarakat Tengger. Laporan Penelitian (Tidak Dipublikasikan), 1991.

[10] Aminuddin. Semantik: Pengantar Sutudi tentang Makna.Bandung:Sinar Baru, 1988.

[11] Sumarsono dan Paina Partana. Sosiolinguistik. Yogyakarta: SABDA, 2004.

[12] Sudaryanto. Metode Linguistik. Yogyakarta: Gajah Mada University Press, 2015.

[13] Sudikan, Setya Yuwono. Metode Penelitian Kebudayaan. Jakarta : Citra Wacana, 2000.

[14] Cruse, D.A. Lexical Semantics. Cambridge: Cambridge University Press, 1986.

[15] Lyons, John. Linguistics Semantics. Cambridge: Cambrridge University Press, 1968.

[16] Pateda, Mansoer. Semantik Leksikal. Jakarta: Rineka Cipta, 2001.

[17] B.W. Setyawan and K. Saddhono, "Eret traditional ceremony as representation of spirit of mutual cooperation among coastal communities". Adv. Sci. Let. vol. 23 no.10, pp 9991-9992, 2017 